УДК: $378: 67 / 78: 67 ; 5 / 5$

DOI:

Магомед Ісаєв, аспірант кафедри державної служби, адміністрування та управління Д3 “Луганський національний університет імені Тараса Шевченка”

\title{
ЕКСПЕРИМЕНТАЛЬНА ПЕРЕВІРКА ЕФЕКТИВНОСТІ МОДЕЛІ УПРАВЛІННЯ ЯКІСТЮ ПІДГОТОВКИ МАЙБУТНІХ ФАХІВЦІВ ФІНАНСОВО-ЕКОНОМІЧНОГО ПРОФІЛЮ В УНІВЕРСИТЕТАХ
}

У статті висвітлено логіку експериментальної перевірки авторських моделей управління якістю підготовки майбутніх фахівиів фінансово-економічного профілю в університетах. Інструментами оцінки якості навчання визначено методи тестування, контрольних зрізів, анкетування, опитування громадськості, відгуки роботодавців та ін. Вихідними даними для оцінки були матеріали статистичного обліку та звітності, результати атестації, моніторингу рівня знань майбутніх фахівиів фінансово-економічного профілю і освітніх програм. Отримані дані було проаналізовано й на їх основі розроблено рекомендації щодо досягнення максимальної ефективності досліджуваного прочесу.

Ключові слова: експериментальна перевірка; модель; майбутні фахівців фінансово-економічного профілю; студенти.

Табл. 2. Літ. 10.

Mahomed Isayev, Postgraduate Student of the Public Service and Management of Educational and Social Institutions Department SI "Luhansk Taras Shevchenko National University"

\section{EXPERIMENTALVERIFICATION OF THE EFFICIENCY OF THE QUALITY MANAGEMENT MODEL OF TRAINING UNIVERSITY STUDENTS MAJORING IN FINANCE AND ECONOMICS}

The article outlines the logic of experimental verification of the author's quality management models of training of university students majoring in Finance and Economics. The tools for assessing the quality of training are the methods of testing, knowledge assessments, questionnaires, public surveys, feedback from employers, etc. The initial data for the assessment were the materials of statistical accounting and reporting, the results of certification, monitoring the level of knowledge of students majoring in Finance and Economics, and educational programs. We analysed the obtained data and developed recommendations for achieving maximum efficiency of the studied process on their basis.

We took into account the results of external monitoring of the quality of professional training of students majoring in Finance and Economics, which was carried out by licensing the right of particular higher educational institutions (HEIs) to carry out educational activities in general and in particular majors, as well as accreditation of HEIs in general and individual educational programs. The internal subjects of monitoring the quality of professional training of students majoring in Finance and Economics include the administration of the HEI, its structural subdivisions; an educational and methodical management of HEI; state attestation commission. The level of professional competence of students majoring in Finance and Economics is of key importance for the quality of education received. Therefore, we decided to compare the level of this competence in students who participated in the experimental study at the beginning and end of our research. We formed the experimental and control groups at universities to achieve the purity of the experiment and to demonstrate the effectiveness of the author's model of the system of professional training of students majoring in Finance and Economics. At the formative stage of the experiment, we oriented students majoring in Finance and Economics to future professions, significantly replenishing their thesaurus, choosing the methods, tools and techniques that would significantly increase the student's activity in the classroom, promote sustainable interest in classes, improve self-esteem, promote the development of qualities.

Keywords: an experimental verification; a model; the students majoring in Finance and Economics.

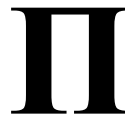
остановка проблеми у загальному вигляді та її зв'язок з важливими науковими чи практичними завданнями. 3 метою доведення ефективності авторської моделі системи управління якістю підготовки майбутніх фахівців фінансовоекономічного профілю в університетах здійснено іiі експериментальну перевірку. Ураховувалося, що для забезпечення якості освіти студентів повинні бути передбачені окремо або в складі наявних структур 3ВО такі координуючі та організаційні підрозділи або групи:

- оцінки і менеджменту якості навчання, 3 функціями розробки технологій і методів аналізу та оцінки якості освітніх програм, контролю виконання державних освітніх стандартів і освітніх 


\section{ЕКСПЕРИМЕНТАЛЬНА ПЕРЕВІРКА ЕФЕКТИВНОСТІ МОДЕЛІ УПРАВЛІННЯ ЯКІСТЮПДГОТОВКИ МАЙБУТНІХ ФАХІВЦІВ ФІНАНСОВО-ЕКОНОМІЧНОГО ПРОФІЛЮ В УНІВЕРСИТЕТАХ}

програм, розробки рекомендацій з управління якістю і контролю за їх реалізацією;

- моніторингу якості знань, умінь, навичок майбутніх фахівців фінансово-економічного профілю в університетах, що сприяє розробці технологій та методів аналізу, самоаналізу і оцінки якості знань та визначення рівня їх освітніх досягнень.

Аналіз останніх досліджень і публікацій, на які спирається автор, в яких розглядають цю проблему і підходи її розв'язання. Ключові засади забезпечення якості професійної підготовки майбутніх фахівців загалом, й фінансово-економічної сферизокрема, активнорозробляються такиминауковцями як Н. Бабкова-Пилипенко [1], О. Булавенко [2], Н. Войнаровська [3], С. Іванченко [4]. Однак нами не знайдено експериментальних спроб перевірки авторських моделей управління якістю підготовки майбутніх фахівців фінансово-економічного профілю в університетах.

Тому метою нашої статті визначено аналіз ефективності реалізації авторської моделі управління якістю підготовки майбутніх фахівців фінансово-економічного профілю в університетах.

Виклад основного матеріалу. Оцінка знань, вмінь і навичок майбутніх фахівців фінансовоекономічного профілю та рівня особистісного розвитку студентів, а також рівня дотримання університетом розроблених постулатів експериментальної системи проводилася на етапі закінчення одного з рівнів освіти - бакалаврської програми підготовки майбутніх фахівців фінансово-економічного профілю.

Інструментами оцінки якості навчання визначено методи тестування, контрольних зрізів, анкетування, опитування громадськості, відгуки роботодавців та ін. Вихідними даними для оцінки були матеріали статистичного обліку та звітності, результати атестації, моніторингу рівня знань майбутніх фахівців фінансово-економічного профілю і освітніх програм [5; 6]. Отримані дані було проаналізовано й на їх основі розроблено рекомендації щодо досягнення максимальної ефективності досліджуваного процесу.

Підкреслимо, що нами взято до уваги результати зовнішнього моніторингу якості професійної підготовки майбутніх фахівців фінансово-економічного профілю, що здійснювався за допомогою ліцензування права конкретних $3 \mathrm{BO}$ здійснювати освітню діяльність в цілому і за конкретними спеціальностями, а також акредитації ЗВО в цілому і окремих освітніх програм [10]. Тоді як внутрішніми суб'єктами моніторингу якості професійної підготовки майбутніх фахівців фінансово-економічного профілю визначено: адміністрацію ЗВО, його структурні підрозділи; навчально-методичне управління 3ВО; державну атестаційну комісію.

Нині внутрішній моніторинг якості освіти у $3 \mathrm{BO}$ включає:

1. Поточний контроль успішності студентів і якості викладання.

2. Проміжний, рубіжний контроль рівня знань майбутніх фахівців фінансово-економічного профілю.

3. Підсумкову атестацію випускників. Поряд 3 цим ключове значення якості отриманої освіти має рівень професійної компетентності майбутніх фахівців фінансово-економічного профілю. Тому прийнято рішення порівняти рівень згаданої компетентності у студентів, котрі брали участь в експериментальному дослідження, на початку і в кінці проведення нашої наукової розвідки [7]. Для досягнення чистоти експерименту i демонстрування ефективності авторської моделі системи професійної підготовки майбутніх фахівців фінансово-економічного профілю в університетах було сформовано експериментальні та контрольні групи. Контрольні групи навчалися за традиційною системою забезпечення якості освіти, експериментальні - відповідно до авторської. Розглянемо отримані результати.

Основними завданнями цього етапу дослідження було:

- вивчення й пояснення якісних і кількісних змін, які отримані в процесі експериментального дослідження у відповідності з виділеними критеріями;

- аналіз отриманих результатів і формулювання загальних висновків.

Проведемо порівняльну характеристику експериментальних і контрольних груп за рівнями сформованості професійної компетентності на початок і наприкінці експерименту.

Відомо, що успішність навчальної діяльності кожного студента, а результативність процесу формування професійної компетентності потребує стійкої мотивації майбутніх фахівців [8]. Тому одним в межах дослідження передбачалося формування стійкого інтересу, позитивноактивного ставлення до навчальної діяльності, творчої позиції майбутніх фахівців фінансовоекономічного профілю на заняттях.

Проведена експериментальна робота сприяла розвитку стійкого інтересу до навчальної діяльності та професійної компетентності в майбутніх фахівців фінансово-економічного профілю експериментальних груп (3 5,5 \% до 14,5 \%), ставлення до навчальної діяльності також змінилося - на початку експериментальної роботи 


\section{ЕКСПЕРИМЕНТАЛЬНАПЕРЕВІРКА ЕФЕКТИВНОСТІ МОДЕЛІ УПРАВЛІННЯ ЯКІСТЮПДГОТОВКИ МАЙБУТНІХ ФАХІВЦІВ ФІНАНСОВО-ЕКОНОМІЧНОГО ПРОФІЛЮ В УНІВЕРСИТЕТАХ}

6 \% майбутніх фахівців фінансово-економічного профілю виявляли позитивно-активне ставлення до навчальної діяльності, після експерименту $51,3 \%$. Слід зазначити, що $14,5 \%$ опитаних студентів експериментальних груп надають перевагу творчій позиції на заняттях (до експерименту 2,8 \%). Динаміка зміни мотивації майбутніх фахівців фінансово-економічного профілю впродовж експерименту відтворена у таблиці 1.

фінансово-економічного профілю впродовж експерименту експериментальних груп прогресує у порівняння 3 констатувальним етапом експерименту.

Для перевірки обсягу знань використовувалася така формула (П.Москаленко).

$$
K_{y(\text { (гp.) }}=\frac{n+n_{1} \cdot 0,8}{n_{0}} \leq 1,
$$

де $\mathrm{K}_{\mathrm{y}}$ - коефіцієнт засвоєння знань,

Таблиця 1.

Динаміка зміни мотивації майбутніх фахівців фінансово-економічного профілю впродовж експерименту (\%)

\begin{tabular}{|c|c|c|c|c|c|c|}
\hline \multirow[t]{3}{*}{ Критерії } & \multicolumn{4}{|c|}{ Експериментальні групи (425 осіб) } & \multirow{2}{*}{\multicolumn{2}{|c|}{$\begin{array}{c}\text { Контрольні групи (105 } \\
\text { осіб) }\end{array}$}} \\
\hline & \multicolumn{2}{|c|}{ До експерименту } & \multicolumn{2}{|c|}{ Після експерименту } & & \\
\hline & $\begin{array}{c}\mathrm{E}-1 \\
(310 \text { осіб) }\end{array}$ & $\begin{array}{c}\text { ЕГ-2 } \\
(115 \text { осіб) }\end{array}$ & $\begin{array}{c}\text { ЕГ-1 } \\
\text { (310 осіб) }\end{array}$ & $\begin{array}{c}\text { ЕГ-2 } \\
(115 \text { осіб) }\end{array}$ & $\begin{array}{l}\text { Контр. } \\
\text { зріз }\end{array}$ & $\begin{array}{l}\text { Конст. } \\
\text { зріз }\end{array}$ \\
\hline \multicolumn{7}{|l|}{ 1. Iнтерес: } \\
\hline Стійкий & 10,3 & 10,8 & 43,9 & 38,2 & 9,5 & 20,2 \\
\hline Відносно стійкий & 48,1 & 46,7 & 46,5 & 52,8 & 48,1 & 62,1 \\
\hline Ситуативний & 40,0 & 42,0 & 10,6 & 10,0 & 41,3 & 18,4 \\
\hline Відсутній & 1,6 & 1,5 & - & - & 1,1 & 0,6 \\
\hline \multicolumn{7}{|c|}{ 2. Відношення до навчальної діяльності: } \\
\hline Позитивно-активне & 8,5 & 9,1 & 51,3 & 52,4 & 5,5 & 10,5 \\
\hline Позитивно-пасивне & 70,5 & 78,3 & 38,2 & 39,8 & 67,4 & 8,5 \\
\hline Нейтральне & 16,9 & 18,0 & 10,5 & 7,8 & 21,6 & 21,0 \\
\hline Негативне & 4,1 & 4,6 & - & - & 5,5 & - \\
\hline \multicolumn{7}{|l|}{ 3. Оиінка власної позиції: } \\
\hline Творча & 2,8 & 3,1 & 15,0 & 17,2 & 4,2 & 8,5 \\
\hline Частково творча & 16,9 & 17,2 & 67,4 & 68,1 & 20,6 & 33,5 \\
\hline Виконавчо-нормативна & 52,3 & 55,7 & 26,2 & 13,9 & 45,4 & 43,0 \\
\hline Пасивна & 28,0 & 24,0 & 1,4 & 0,8 & 29,8 & 15,0 \\
\hline
\end{tabular}

Нас цікавило й те, наскільки виявляли захопленість у вивченні дисциплін, зміст яких відтворює обрану проблему. Це виявилося в тому, що вони постійно цікавилися літературою 3 обраної проблеми, самостійно її опрацьовували, почали надавати перевагу активній позиції на заняттях, здійснювався постійний контроль і самоконтроль.

Вважаємо, що отримані результати можна пояснити тим, що в процесі занять постійно акцентувалася увага на значущості професійної компетентності, необхідності й доцільності їі формування, здійснювалася оріснтація на розвиток інтересу до навчальної діяльності, а також постійне використання ігрових технологій, створення позитивного мікроклімату на заняттях.

Як видно $з$ таблиці, динаміка всіх критеріїв мотивації формування професійної компетентності та навчальної діяльності у майбутніх фахівців $\mathrm{n}_{0}$ - можлива кількість засвоєних повних $\mathrm{i}$ правильних відповідей майбутніх фахівців фінансово-економічного профілю,

$\mathrm{n}$ - кількість засвоєних правильних і неповних відповідей.

Глибина засвоєння знань визначалася за такими критеріями: причиново-наслідкові зв'язки майбутні фахівці фінансово-економічного профілю встановлювали повністю; частково; не встановлювали. Додатково використовувалася формула:

$$
R_{y(2 p .)}=\frac{R+R_{1} \cdot 0,8}{R_{0}} \leq 1,
$$

де $\mathrm{R}_{\mathrm{y}}$ - глибина засвоєння знань,

$\mathrm{R}_{0}$ - можлива кількість правильно виділених причиново-наслідкових зв'язків,

$\mathrm{R}_{1}$ - кількість правильних і неповно виділених причиново-наслідкових зв’язків. 


\section{ЕКСПЕРИМЕНТАЛЬНАПЕРЕВІРКА ЕФЕКТИВНОСТІ МОДЕЛІ УПРАВЛІННЯ ЯКІСТЮПДГОТОВКИ}

МАЙБУТНІХ ФАХІВЦІВ ФІНАНСОВО-ЕКОНОМІЧНОГО ПРОФІЛЮ В УНІВЕРСИТЕТАХ

При перевірці обсягу і глибини знань майбутніх фахівців фінансово-економічного профілю використовувалися конкретні завдання, які вимагали розкриття в судженнях змісту поняття, виявлення його суттєвих ознак, їх кількість і значення, встановлення причинно-наслідкових зв'язків. При перевірці обсягу і глибини знань фіксувалися судження й аргументації, оцінювалася ступінь усвідомлення необхідних понять та їх ознак, грамотність і обгрунтування висловлювань.

Результати зміни об'єму і глибини засвоєння знань майбутніх фахівців фінансово-економічного профілю показано в таблиці 2.

Порівнюючи табличні дані, що були отримані на початку i наприкінці педагогічного експерименту, ми дійшли висновку, що відбулося зростання об'єму знань студентів, цьому сприяло розв'язання проблемних ситуацій та професійний ситуацій, організація мінідіалогів, використання проектних та проблемних методів навчання.

Засвоєні знання сприяли формуванню професійних умінь майбутніх фахівців фінансовоекономічного профілю. Дієвість знань характеризували процентним відношенням кількості правильно даних відповідей, виконаних операцій, дій в кожному завданні, до всієї суми таких логічних одиниць, які приходяться на всю роботу курсу [9]. Наприклад, завдання складається з чотирьох логічних одиниць, тому треба дати чотири відповіді. Якщо майбутній фахівець фінансово-економічного профілю дав тільки дві правильні відповіді, значить він недостатньо засвоїв інформацію теми, тобто показник дієвості дорівнює 52 \%.

Для встановлення показника дієвості визначаємо, скільки сенсових (логічних) одиниць включає це завдання (m). В цілому для курсу це буде складати:

$$
M=m^{*} n,
$$

де $\mathrm{n}$ - кількість майбутніх фахівців фінансовоекономічного профілю, які виконували завдання.

Підрахуємо, скільки сенсових (логічних) одиниць у відповідях кожного майбутнього фахівця фінансово-економічного профілю. Потім визначаємо, скільки сумарно у відповідях майбутніх фахівців фінансово-економічного профілю дано сенсових одиниць - N.

Показник дієвості знань визначається відношенням:

$$
\text { ПД }=\frac{N}{M} \cdot 100 \%,
$$

Перший контрольний зріз показав, що майбутніх фахівців фінансово-економічного профілю експериментальних груп використовували майже вже 78,4 \% засвоєних раніше знань, а майбутніх фахівців фінансово-економічного профілю контрольних - тільки 53,2 \%.

Згодом був зроблений другий зріз, який показав, що дієвість знань залишається високою в експериментальних групах. У контрольних групах також піднявся рівень дієвості знань до 49,3 \%. Ми вважаємо, що це було досягнуто за рахунок оволодіння майбутніми фахівцями фінансово-економічного профілю вмінням виділяти в навчальній інформації основне.

У кінці експериментального навчання було зроблено перший контрольний зріз, який показав, що майбутні фахівці фінансово-економічного профілю експериментальних груп дієвіше засвоїли знання - 74,6 \% запропонованих завдань було

Таблиця 2.

\begin{tabular}{|c|c|c|c|c|c|c|}
\hline \multirow{3}{*}{$\begin{array}{c}\text { Показники об’єму та } \\
\text { глибини засвоєння } \\
\text { знань }\end{array}$} & \multicolumn{4}{|c|}{ Експериментальні групи (425 осіб) } & \multirow{2}{*}{\multicolumn{2}{|c|}{$\begin{array}{c}\text { Контрольні групи (105 } \\
\text { осіб) }\end{array}$}} \\
\hline & \multicolumn{2}{|c|}{ До експерименту } & \multicolumn{2}{|c|}{ Після експерименту } & & \\
\hline & $\begin{array}{c}\mathrm{E} \Gamma-1 \\
(310 \text { осіб) }\end{array}$ & $\begin{array}{c}\mathrm{E} \Gamma-2 \\
(115 \text { осіб) }\end{array}$ & $\begin{array}{c}\mathrm{E} \Gamma-1 \\
(310 \text { осіб })\end{array}$ & $\begin{array}{c}\mathrm{E} \Gamma-2 \\
(115 \text { осіб })\end{array}$ & $\begin{array}{c}\text { Контр. } \\
\text { зріз }\end{array}$ & $\begin{array}{c}\text { Конст. } \\
\text { зріз }\end{array}$ \\
\hline $\begin{array}{l}\text { Коефіцієнт ступеня } \\
\text { засвоєння знань }\end{array}$ & 0,27 & 0,31 & 0,78 & 0,79 & 0,22 & 0,24 \\
\hline $\begin{array}{ll}\text { Коефіцієнт } & \text { ступеня } \\
\text { глибини знань } & \end{array}$ & 0,26 & 0,32 & 0,72 & 0,61 & 0,23 & 0,23 \\
\hline $\begin{array}{l}\text { Причинно-наслідкові } \\
\text { 3в’язки } \quad \text { встановлено } \\
\text { повністю }\end{array}$ & - & - & 13,2 & 7,6 & - & - \\
\hline $\begin{array}{l}\text { Причинно-наслідкові } \\
\text { зв’язки } \quad \text { встановлено } \\
\text { частково }\end{array}$ & 35,9 & 21,2 & 52,6 & 44,8 & 29,7 & 31,4 \\
\hline $\begin{array}{l}\text { Причинно-наслідкові } \\
\text { зв'язки не встановлено }\end{array}$ & 63,7 & 78,9 & 34,1 & 47,4 & 70,0 & 67,9 \\
\hline
\end{tabular}

Динаміка об’єму та глибини засвосння знань 


\section{ЕКСПЕРИМЕНТАЛЬНА ПЕРЕВІРКА ЕФЕКТИВНОСТІ МОДЕЛІ УПРАВЛІННЯ ЯКІСТЮПДГОТОВКИ}

МАЙБУТНІХ ФАХІВЦІВ ФІНАНСОВО-ЕКОНОМІЧНОГО ПРОФІЛЮ В УНІВЕРСИТЕТАХ

виконано проти 49,2 \% у контрольних групах. Через два місяці дієвість знань майбутніх фахівців фінансово-економічного профілю експериментальних груп залишалася значно вищою ніж дієвість знань студентів контрольних груп (68,4 \% проти 49,2 \%). Невелике зниження дієвості знань мало місце в результаті природного процесу забування.

Оскільки, майбутні фахівці фінансовоекономічного профілю контрольних груп знайомилися з теоретичними питаннями стосовно професійної компетентності тільки на декількох заняттях зі спеціальності, цілком закономірно, що рівень їхніх знань 3 цього питання був обмежений межами університетської програми. Якісний аналіз результатів показав, що майбутні фахівці фінансово-економічного профілю вільно володіють спеціальними поняттями та видами знань, обізнані 3 поняттям “професійна компетентність”, іiї сутності та компонентами, розуміють сутність цінностей-знань, теоретично правильно обгрунтовують залежність між рівнями сформованості компонентів професійної компетентності та їх впливом на результативність навчальної діяльності. Значно зросла кількість правильних повних відповідей, що свідчить про цілеспрямованість і усвідомленість навчальної діяльності, правильність обраних засобів, способів і прийомів, які впливають на формування професійної компетентності.

У процесі формувального етапу експерименту орієнтували майбутніх фахівців фінансовоекономічного профілю на майбутні професії, значно поповнюючи їхній тезаурус, обирали такі способи, засоби та прийоми, які значно підвищували активність студентів у процесі занять, сприяли формуванню стійкого інтересу до занять, підвищенню самооцінки знань, розвитку якостей. Від завдань за алгоритмом переходили до завдань творчих, постійно розв'язуючи професійні задачі, котрі вимагали творчого застосування набутих знань. У зв'язку з цим і зросла якість знань, і загалом професійної підготовки майбутніх фахівців фінансовоекономічного профілю.

Успішність навчальної діяльності майбутніх фахівців фінансово-економічного профілю в університетах, а також професійної діяльності визначають розвинені інтелектуальні уміння. Саме тому в дослідженні їм приділили особливу увагу. Виконання завдань різного типу (від репродуктивних до творчих), розв'язання професійних задач дозволило сформувати уміння виділяти головне в змісті тексту або завдання, що сприяло більш глибокому їх розумінню. Аналіз діагностичних контрольних робіт підтвердив пряму залежність між сформованістю уміння виділяти головне і появою обгрунтованих відповідей студентів, усвідомлених оцінних знань.

Аналіз результатів зрізів свідчить, що уміння виділяти головне, основне в інформації сприяло дієвому засвоєнню знань студентами, особливо засвоєнню визначень, виконанню порівнянь та встановленню причиново-наслідкових зв'язків. При цьому, характер застосування знань частіше був творчим, ніж виконавчим, а засвоєння знань проходило на комбінаційному рівні, тому що формування у майбутніх фахівців фінансовоекономічного профілю уміння виділяти головне, основне в тому, що вивчається, вимагало мислительної роботи студентів щодо знаходження, встановлення цього головного: думок, словесних виразів, котрі визначають основну сутність даної проблеми, з наступним формулюванням цього основного в усній формі або письмового запису.

Висновок. У ході експериментального дослідження було встановлено, що вміння виділяти головне має і виховний вплив. Так, нами було встановлено, що більшість майбутніх фахівців фінансово-економічного профілю набули таких якостей як цілеспрямованість, активність, зібраність, відповідальність, дисциплінованість. Набуте уміння виділяти головне студенти почали використовувати при оволодінні іншими предметами. Проведена експериментальна робота сприяла формуванню вмінь узагальнення. В психології виділяють три рівні складності розумової діяльності: активне мислення, продуктивне і творче. Встановлено, що динаміка формування професійної компетентності в процесі навчальної діяльності підтверджує позитивний вплив моделі системи управління якістю професійної підготовки майбутніх фахівців фінансово-економічного профілю на розвиток цього складника фахового навчання студентів.

Перспективи подальших розвідок у цьому напрямі вбачаємо в розробці рекомендації щодо ефективного управління якістю підготовки майбутніх фахівців фінансово-економічного профілю.

\section{ЛІТЕРАТУРА}

1. Бабкова-Пилипенко Н. П. Формування лідерських якостей майбутніх економістів у процесі професійної підготовки : дис. ... канд. пед. наук : спец. 13.00.04. Ялта, 2011. 242 с.

2. Булавенко О. Проектирование содержания и технологии непрерывного экономического образования в профессиональных учебных заведениях : автореф. дис. на соискание научн. 


\section{ЕКСПЕРИМЕНТАЛЬНА ПЕРЕВІРКА ЕФЕКТИВНОСТІ МОДЕЛІ УПРАВЛІННЯ ЯКІСТЮПДГОТОВКИ МАЙБУТНІХ ФАХІВЦІВ ФІНАНСОВО-ЕКОНОМІЧНОГОПРОФІЛЮ В УНІВЕРСИТЕТАХ}

степени доктора пед. наук : спец. 13.00.08. Брянск, 2007.

3. Войнаровська Н. В. Підготовка бакалаврів з економіки у вищих навчальних закладах США : автореф. дис. на здобуття наук. ступеня канд. пед.наук : спец. 13.00.01 “Загальна педагогіка та історія педагогіки”. Вінниця, 2011. 20 с.

4. Іванченко С. Професіоналізм як складова компетентності економіста та його оцінювання в системі інтегративної професійної підготовки майбутніх економістів. Вісник Дніпропетровського університету. Серія “Педагогіка і психологія". №9/1. Вип. 15. 2009. С. 178-186.

5. Asan, S. S., \& Tanyas, M. Integrating Hoshin Kanri and the Balanced Scorecard for Strategic Management: The case of higher education. Total Quality Management and Business Excellence. 2007. No. 18(9). pp. 999-1014.

6. Campatelli, G., Citti, P., \& Meneghin, A. Development of a simplified approach based on the EFQM model and Six Sigma for the implementation of TQM principles in a university administration. Total Quality Management and Business Excellence. 2011. No. 22(7), pp. 691-704.

7. ISO 9001:2015 Quality management systems - Requirements: Guidance Document. Electronic Recourse. Mode of URL: file://C:/Users/User/ Downloads/ISO\%2090 01\%202015 \%20 GUIDANCE\%20DOCUMENT tcm18-49893.pdf

8. Sarrico, C. S., Rosa, M. J., Teixeira, P. N., \& Cardoso, M. F. Assessing quality and evaluating performance in higher education: worlds apart or complementary views? Minerva. 2010. No.48. pp. $35-54$.

9. Standards and Guidelines for Quality Assurance in the European Higher Education Area (ESG). 2015. Brussels, Belgium. URL: https://enqa.eu/wp-content/ uploads/2015/11/ESG_2015.pdf

10. Rosa, M., Kohoutek, J., Veiga, A., and Sarrico, C. The European Standards and Guidelines for Quality Assurance in the European Higher Education Area in Portugal and the Czech Republic: between the worlds of neglect and dead letters? Higher Education Policy. 2018. No/ 31,2. pp. 201-224.

\section{REFERENCES}

1. Babkova-Pylypenko, N. P. (2011). Formuvannia liderskykh yakostei maibutnikh ekonomistiv u protsesi profesiinoi pidhotovky [Formation of leadership qualities of future economists in the process of professional training]. Candidate's thesis. Yalta, $242 \mathrm{p}$. [in Ukrainian].

2. Bulavenko, O. (2007). Proektirovanie soderzhaniya i tekhnologii nepreryvnogo ekonomicheskogo obrazovaniya $\mathrm{v}$ professionalnykh uchebnykh zavedeniyakh [Designing the content and technology of continuous economic education in professional educational institutions]. Extended abstract of candidate's thesis. Bryansk. [in Russian].

3. Voinarovska, N. V. (2011). Pidhotovka bakalavriv $\mathrm{z}$ ekonomiky u vyshchykh navchalnykh zakladakh SShA[Training of Bachelors of Economics in the US Higher Educational Institutions]. Extended abstract of candidate's thesis Vinnytsia. [in Ukrainian].

4. Ivanchenko, Ye. (2009). Profesionalizm yak skladova kompetentnosti ekonomista ta yoho otsiniuvannia $\mathrm{v}$ systemi intehratyvnoi profesiinoi pidhotovky maibutnikh ekonomistiv [Professionalism as a component of the economist's competence and its evaluation in the system of integrative professional training of future economists]. Bulletin of Dnipropetrovsk University. Series "Pedagogy and Psychology”. No.9/1. Vol. 15. pp. 178-186. [in Ukrainian].

5. Asan, S. S., \& Tanyas, M. (2007). Integrating Hoshin Kanri and the Balanced Scorecard for Strategic Management: The case of higher education. Total Quality Management and Business Excellence. No. 18(9). pp. 999-1014.[in English].

6. Campatelli, G., Citti, P., \& Meneghin, A. (2011). Development of a simplified approach based on the EFQM model and Six Sigma for the implementation of TQM principles in a university administration. Total Quality Management and Business Excellence. 2011. No. 22(7), pp. 691-704.[in English].

7. ISO 9001:2015 Quality management systems - Requirements: Guidance Document. Electronic Recourse. Mode of Available at: file:///C:/Users/User/

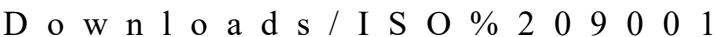
\%202015\%20GUIDANCE\%20DOCUMENT tcm1849893.pdf[in English].

8. Sarrico, C. S., Rosa, M. J., Teixeira, P. N., \& Cardoso, M. F. (2010). Assessing quality and evaluating performance in higher education: worlds apart or complementary views? Minerva. No.48. pp. 35-54.[in English].

9. Standards and Guidelines for Quality Assurance in the European Higher Education Area (ESG). 2015. Brussels, Belgium. Available at: https://enqa.eu/wpcontent/uploads/2015/11/ESG 2015.pdf[in English].

10. Rosa, M., Kohoutek, J., Veiga, A., \& Sarrico, C. (2018). The European Standards and Guidelines for Quality Assurance in the European Higher Education Area in Portugal and the Czech Republic: between the worlds of neglect and dead letters? Higher Education Policy. No. 31,2. pp. 201-224. [in English].

Стаття надійшла до редакції 09.06.2020 